\title{
ECB: Time Is Ripe for a Real Strategy
}

When Mario Draghi took over the helm of the ECB in November 2011, the euro area was in a perfect storm. The crisis was triggered by the sudden realisation of Greece's excessive public debt in early 2010 and capital investors' reluctance to buy new Greek bonds. The instability was rapidly spilling over to other peripheral countries. It was reinforced by a statement by Chancellor Merkel and President Sarkozy on 19 October 2011 in Deauville where they agreed that in the future, sovereign bailouts from the European Stability Mechanism would require that losses be imposed on private creditors. But the ECB itself had also contributed to magnifying the pressure as it raised interest rates in April 2011 and again in July 2011, even though the crisis was already well under way.

Draghi's first prank was a very extensive long-term refinancing operation which started on $21 \mathrm{De}-$ cember 2011. It was respectfully referred to by market participants as Dicke Berta, the name of a powerful gun used by the Germans in World War I. This refinancing operation enabled banks in Italy and Spain in particular to acquire domestic government bonds on a large scale. It was therefore an indirect form of 'quantitative easing'. But this measure was not able to stabilise the situation. The German government was not prepared to create forms of joint liability for government bonds, as it basically valued market pressure as a disciplining element for the peripheral countries. Thus, centrifugal forces continued to increase in the early summer of 2012. The markets began to bet on the disintegration of the monetary union. In this almost hopeless situation, Draghi proved to be the saviour of the euro. With his striking statement "whatever it takes" on 26 July 2012, he succeeded in turning the wheel. Market expectations changed abruptly from a bad to a good equilibrium. The ECB endorsed this statement with the decision to support a country in a crisis with Outright Monetary Transactions.

At the same time, the ECB gradually moved key interest rates to zero lower bound. The supportive monetary environment freed the peripheral countries from the grip of the hectic financial markets. They were no longer forced into austerity at any price. With a more cautious fiscal policy and falling lending rates, the crisis countries succeeded in stopping the recession and returning to a growth path. Unemployment, which had once again risen sharply in 2011 and 2012, was slowly declining.

The third major strategic move took place in the second half of 2014. Under the impression of falling inflation expectations, the ECB decided on a comprehensive purchasing programme for both public and private bonds. It thus followed the practice of other major central banks that had launched such programmes immediately after the onset of the global financial crisis.

In September 2019, shortly before the end of Draghi's term, the ECB decided to lower its interest rates further and resume bond buying. In doing so, it took into account the recessionary tendencies in the euro area that were emerging in 2019 and at the same time the fact that governments showed no willingness to become active in fiscal policy.

If one judges Draghi's term of office on the basis of the ECB's mandate, set out in the treaty, which states that its primary objective is price stability, one can hardly accuse him of having been too expansive in his policy. Looking back, it can be said that the ECB avoided deflation. The fact that core inflation in the euro area has remained at around $1 \%$ in recent years does not argue against the effectiveness of bond purchases. On the contrary, it shows that deflationary forces appeared to have been very strong. For the coming years, too, the Survey of Professional Forecasters shows that inflation expectations are below the ECB target of "below but close to 2\%".

Draghi's critics have been accusing him for years of destabilising the financial system. Low interest rates would lead market participants to take excessive risks, asset prices would be inflated and banks' earning power would suffer. In its annual report 2016/17, the majority of the German Council of Economic Experts even warned that this would lead to a new financial crisis. However, 
in view of the very low interest rates that have now been in place for years, the indications of dangerous distortions in the financial system of the euro area are extremely sparse. Bank lending to the private sector in the aggregate and also in individual member states is developing moderately. Real estate prices have risen more sharply in some countries, but developments are far from the excesses in the years before the global financial crisis. The earnings situation of banks in the euro area is unsatisfactory, especially in Germany. But in the German case, these are mainly the problems of individual large banks that cannot be attributed to the ECB's monetary policy.

Draghi is particularly criticised in the German public, but also by German economists. Draghi's critics are not deterred by the fact that, for years, they have been predicting inflationary effects of his policies that never occurred. They see the ECB's bond purchases as a rescue programme for periphery countries and fail to recognise that all the major central banks are using this instrument. Even the Deutsche Bundesbank made large purchases of government bonds in the 1970s.

The now proverbial 'German saver' plays a major role in the German debate. It is deplored that the zero interest rate policy means that the saver is no longer in a position to increase his wealth appropriately by saving. However, this does not take into account the fact that the income from saving depends not only on the interest rate but also on the rate of inflation. Technically speaking, this is referred to as a 'money illusion'. Taking the inflation rate into account, the situation of the German saver is much less dramatic. According to statistics from the Deutsche Bundesbank, the average real interest rate from 1967 until the end of the Deutschmark era in December 1998 was $-0.004 \%$. Under the aegis of Draghi it was $-0.7 \%$, which does not make a fundamental difference. However, there are also solid economic reasons for the Germans' dissatisfaction with Draghi's policies. Compared with the other euro area member states, many German households have no residential property. The home ownership rate of $45 \%$ is far below the values of countries like Spain (78\%) or Italy (77\%). This at least partly reflects misguided German policies in the 2000 s when all subsidies for the purchase of homes were removed, while very generous subsidies for investments in insurance savings were introduced.

The fact that the ECB has failed in recent years to present a broadly successful policy to the general public reflects a deeper problem. The so-called two-pillar strategy, developed back in 1998, is unable to explain the ECB's policy not only to the broader public, but also the scientific community. First and foremost, the function of a strategy must be to reduce the complexity of the macroeconomic environment and the required monetary policy measures in such a way that the approach of the central bank becomes transparent and thus comprehensible to the outside.

It was obvious from the very beginning that the two-pillar strategy was inadequate. With its 'economic analysis' and 'monetary analysis', the strategy simply stated the obvious, i.e. that the ECB will monitor all relevant real and monetary data in its decision-making process. The only reduction of complexity was provided by a reference value for the growth rate of the money stock M3. But this heritage from the Bundesbank's strategy was flawed and after some years completely discarded.

Thus, the time is ripe for a real strategy. The strategy of inflation targeting, which is widely used by central banks, seems to be the most promising. The ECB is already de facto practicing an implicit inflation targeting. Its staff is producing 'inflation projections' on a quarterly basis, which are presented in the ECB's press conferences. Explicit inflation targeting, in which inflation forecasts are continually compared to the ECB's inflation target, creates an operational framework for monetary policy discussion. Above all, it forces critics of the ECB to make their own inflation forecast, which can then be evaluated ex post.

Peter Bofinger, University of Würzburg, Germany.
All in all, Mario Draghi was a godsend for the ECB and the euro area. He steered the euro safely through heavy seas. There is a certain irony here that the Germans, who benefited in a special way from the stability of the monetary union, did not thank him for that. 